\title{
Pueraria tuberosa as Dipeptidyl-Peptidase-IV Inhibitor Prevents Streptozotocin-Induced Intestinal Stress
}

\author{
Shivani Srivastava ${ }^{1}$, Harsh Pandey ${ }^{1}$, Surya Kumar Singh ${ }^{2}$, Yamini Bhusan Tripathi ${ }^{1 *}$ (D) \\ ${ }^{1}$ Department of Medicinal Chemistry, Institute of Medical Sciences, Banaras Hindu University, India; ${ }^{2}$ Department of \\ Endocrinology and Metabolism, Institute of Medical Sciences, Banaras Hindu University, India
}

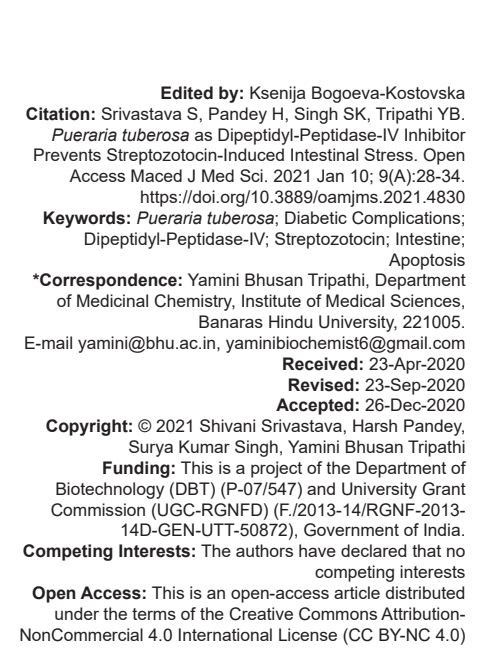

\begin{abstract}
BACKGROUND: Enhanced expression of dipeptidyl-peptidase-IV (DPP-IV) has been found in various intestinal diseases. Pueraria tuberosa tuber water extract (PTY-2) is already known to have DPP-IV inhibitory potential. At the mRNA level, this inhibition has not yet been investigated. Increased incretin secretion due to inhibition of DPP-IV could lead to the suppression of stress and apoptosis of intestinal cells.

AIM: In this research, we tried to study the antioxidant, anti-apoptotic, and DPP-IV inhibitory effect of PTY 2 against intestinal damage induced by STZ.

METHODS: We found morphological damage to the intestine following streptozotocin (STZ) injection (65 mg/kg bw) in male Charles foster rats through histological examination. Superoxide dismutase (SOD) and DPP-IV mRNA expressions were analyzed by polymerase chain reaction and cell apoptosis was examined by tunnel assay and $\mathrm{Bcl}$ 2 immunoexpression.

RESULTS: In STZ-induced diabetic control, the number and length of villi were decreased, but these damages were reversed by 10 days of PTY-2 treatment. SOD expression was found to be decreased whereas DPP-IV expression was enhanced with significant intestinal cell apoptosis in the diabetic control group. Treatment with PTY-2 decreases stress by upregulating SOD expression and by downregulating the expression of DPP-IV. These PTY-2 recoveries contribute to the suppression of apoptosis in the intestinal cells.

CONCLUSION: The protective action of PTY-2 against STZ mediated intestinal damage is demonstrated by these
\end{abstract} short studies. Therefore, PTY-2 may be taken as a herbal remedy for diabetes-induced intestinal damages.

\section{Introduction}

Streptozotocin (STZ) has been used to induce diabetic experimental models since 1963. The STZ enters through glucose transporter 2 (GLUT 2) transporter and harms $\beta$ cells by methylation of deoxyribonucleic acid (DNA) and by acting as a donor of nitric oxides. GLUT 2 transporters are also responsible for STZ uptake into the epitheliocytes of the intestinal mucosa, renal tubule cells, and hepatocytes, in addition to pancreatic $\beta$-cells. It means STZ is also toxic to the cells of other organ, which expresses the GLUT 2 transporter [1]. Several herbals have been studied to improve intestinal deformities against STZinduced diabetes, such as Azadirachta indica [1], green tea extract, and ginseng root [2].

A cell-surface protease, dipeptidyl-peptidase IV (DPP IV)/CD26 belongs to the prolyl oligopeptidase family. By removing the $\mathrm{N}$-terminal dipeptide with proline or alanine in the second position, it makes several bioactive peptides (Glucagon-like peptides [GLP-1, GLP-2], GIP, etc.) inactive [3]. Within the gastrointestinal tract, glucagon like peptides plays an important role towards gut adaptation. After their synthesis, they get released into the intestine from the enteroendocrine cells. GLP-1 efficiently engages the enteric nervous system, thereby regulates gut motility and activates gut-brain axis that controls insulin secretion, glucose disposal in peripheral tissues, and blood flow [4], [5]. GLP-2 cosecreted from the $L$ cells together with GLP-1 and acting more proximally in the gut to increase the absorption of the nutrient [5], [6]. The valine-pyrrolidide inhibition of DPP-IV decreases GLP-2 degradation and improves its intestinotrophic effect such as growth of the intestines [7].

The differentiation-dependent expression of DPP-IV in the crypt-villus axis of rat jejunum is primarily controlled at the level of messenger ribonucleic acid (mRNA) [8], according to a previous report. It is also reported that the promotion and formation of intestinal ulcers are prevented by DPP-IV inhibition [9]. Thus, DPP-IV inhibitors and glucagon like peptides play an important role in maintaining intestinal health. We have already reported the DPP-IV inhibitory role of Pueraria tuberosa tuber water extract (PTY 2) in blood and intestinal homogenate [10], [11], [12]. Here, we further studied the DPP-IV inhibitory property of PTY2 in the 
intestinal duodenum at the mRNA level and used this property to focus on intestinal damage caused by STZ. $P$. tuberosa possesses many medicinal properties as an antioxidant [13], [14] and an anti-inflammatory agent [15]. It is highly effective in the treatment of diabetes [10], [11], [16], nephropathy [17], anxiolytic [18], antihypertension [19], etc. The key constituents of $P$. tuberosa are steroids, glycosides, triterpenoids, flavonoids, carbohydrates, tannins, proteins, alkaloids, and amino acids, such as puerarin 4',6'-diacetate, tuberosin, daidzin, genistein, puerarin, puetuberosanol, puerarone, and tuberostan [10], [20], [21]. we have hypothesized that treatment with PTY 2 may be responsible for improving intestinal health. In this research, we tried to study the antioxidant, anti-apoptotic, and DPP-IV inhibitory effect of PTY 2 against intestinal damage induced by STZ.

\section{Materials and Methods}

\section{Materials}

Rabbit polyclonal Bcl 2 (26 KDa) (N-19): sc-492, EZ Retrieval System V.3 (Bio Genex), Zeiss LSM510 Meta confocal microscope, and Zen Black (2012) software was used for immunohistochemistry (IHC). For histology analysis, Hematoxylin-Eosin (HE), Nikon microscope (Eclipse 50i, loaded with imaging softwareNIS Elements Basic research), and Leica RM2125 room temperature (RT) rotator microtome (Leica Biosystems Nussloch $\mathrm{GmbH}$, Nussloch, Germany) were used "TACS $尺 2$ TdT Fluorescein Kit - Trevigen" for the analysis of apoptosis. For reverse transcription polymerase chain reaction (RT-PCR), Trizol (HiMedia, Pvt. Ltd, Kolkata, India), cDNA Kit (Fermentas), and Taq-polymerase (GenaxyScientific Pvt.Ltd) were used.

\section{Sample preparation}

$P$. tuberosa had been purchased from Banaras Hindu University's Ayurvedic Pharmacy. Our previous laboratory research [14] has already proven its authenticity. With 8 volumes of distilled water, $30 \mathrm{~g}$ of tuber powder have been extracted. When the volume decreased to one-fourth, the extract obtained was then filtered with cloth. Through this procedure, the total yield was $30 \%$ [16].

\section{Animals design}

After acclimatization, Charles foster male rats of the same age group and a weight range of 120-130 g were injected STZ (65 mg/kg bw), prepared in fresh and chilled citrate buffer ( $\mathrm{pH} 4.5)$, after overnight fasting for 8 $\mathrm{h}$. The diabetic condition was checked on the $5^{\text {th }}$ day with the use of glucometer strips (Dr. Morepen). Rats with blood glucose levels above $200 \mathrm{mg} / \mathrm{dL}$ were considered diabetic and kept for 60 days to induce severe diabetes (three rats per cage). On day 61, the rats were divided into three groups ( $n=6$ ): Group-1 (STZ untreated rats, i.e., age-matched normal control), Group-2 (diabetic control), and Group-3 (PTY-2 at $50 \mathrm{mg} / 100 \mathrm{~g}$ bw treatment for 10 days to diabetic rats). After 10 days, the rats were sacrificed and intestinal duodenum was isolated. Each intestinal sample was divided into two parts; one for histology and IHC (preserved in 10\% formaldehyde) and the other was first crushed in liquid nitrogen and then stored in $-80^{\circ} \mathrm{C}$ freezer for molecular analysis [16].

\section{Hematoxylin and eosin (HE) staining}

Intestinal tissues fixed with formalin were embedded in paraffin wax. Using Leica RM2125 RT rotator microtome (Leica Biosystems Nussloch $\mathrm{GmbH}$, Nussloch, Germany), the tissues were cut into $4 \mu \mathrm{m}$ thick sections. Every section was stained with $\mathrm{HE}$ and then imaged and observed using Nikon microscope (Eclipse $50 \mathrm{i}$, loaded with imaging software-NIS Elements Basic research).

\section{Tunnel assay}

Identification and quantification of apoptosis were done using a tunnel assay "TACS $尺 2$ TdT Fluorescein Kit - Trevigen."

\section{Immunohistochemical staining}

Dewaxed the intestinal tissues using xylene for 10 min and through 90\%, 70\% alcohol and water, tissues were then rehydrated serially in each for $5 \mathrm{~min}$. Then after, each slide get dipped in citrate buffer and proceeded for antigen retrieval using EZ Retrieval System V.3 (Bio Genex). Sections were washed 2 times with phosphate buffered saline (PBS) for $10 \mathrm{~min}$ each, and then blocked with $0.1 \%$ Triton $\mathrm{X}-100,0.1 \%$ bovine serum albumin, $10 \%$ fetal bovine serum, $0.1 \%$ sodium deoxycholate, and $0.02 \%$ Thiomersal (anti-fungal agent) in $1 \mathrm{X}$ PBS for $2 \mathrm{~h}$ at RT. All sections were then incubated overnight with the primary antibodies at $4^{\circ} \mathrm{C}$ and then washed with phosphate-buffered saline with tween 20 (PBST) thrice for 10 min each, followed by incubating each section with anti-rabbit-AF 546 (Red) (Invitrogen, USA) secondary antibodies at RT for $2 \mathrm{~h}$. Again washed thrice in PBST for 10 min each. Finally, counterstained with DAPI $(1 \mu \mathrm{g} /$ $\mathrm{ml}$ DAPI in $1 \mathrm{X}$ PBS) and mounted on DABCO. Using Zeiss LSM510 Meta confocal microscope, all the slides were examined. Zen Black (2012) software was used for image analysis.

\section{RT-PCR}

Using trizol, we have homogenized $50 \mathrm{mg}$ of the intestinal tissue. With random hexamers and superscript II RNase H-RT, $5 \mu \mathrm{g}$ of total RNA was 
reverse-transcribed. For DPP-IV, $2 \mu \mathrm{l}$ cDNA, $0.2 \mathrm{mmol} / \mathrm{L}$ dNTPs, $1.5 \mathrm{mmol} / \mathrm{L} \mathrm{MgCl}_{2}, 0.5 \mu \mathrm{mol} / \mathrm{L}$ of each primer, $2.5 \mu \mathrm{l} 10 \times$ PCR buffer, and $1 \mathrm{U}$ Taq DNA polymerase were used. The reaction mix for Sod included 2 $\mu$ c-DNA, 0.2mM dNTPs, $1.5 \mathrm{mM} \mathrm{MgCl}$, $0.5 \mu \mathrm{M}$ of each primer, $2.5 \mu \mathrm{l} 10 \times$ PCR buffer, and 1UTaq DNA polymerase. For glyceraldehyde 3-phosphate dehydrogenase (GAPDH), $0.1 \mu \mathrm{mol} / \mathrm{L}$ of each primer was used. Expressions optical density was determined and presented as a ratio against GAPDH with the help of an alpha imager (Bio-Rad). All the expressions were checked in triplicate (Table 1).

\section{Results}

\section{Histological examination}

STZ induces a hazardous effect on the intestinal morphology by reducing the overall length and number of intestinal villi. The PTY 2 significantly reversed the intestinal damage caused by STZ in 10 days of treatment. Therefore, PTY 2 enhances the surface area of the intestine, leading to enhanced absorption of nutrients and minerals (Figure 1).

\section{Apoptosis}

The sections of STZ control groups have shown significant intestinal damage accompanied by cell apoptosis. However, PTY 2 treatment for 10 days significantly prevented this damage (Figure 2).

IHC analysis also proved the anti-apoptotic effect of PTY 2 on intestinal cells. It significantly reversed the downregulation of $\mathrm{Bcl} 2$ expression induced by STZ (Figure 3).

\section{mRNA expressions}

PTY 2 recovers the STZ induced stress; as a result, the expression of SOD was significantly enhanced. In the other hand, we have also found the reduced mRNA expression of stress marker DPP-IV in PTY 2 treated group. This clearly shows the potential of PTY 2 against STZ-induced intestinal damage (Figure 4).

\section{Discussion}

During diabetes, the morphologies and functions of the small intestine get highly altered.

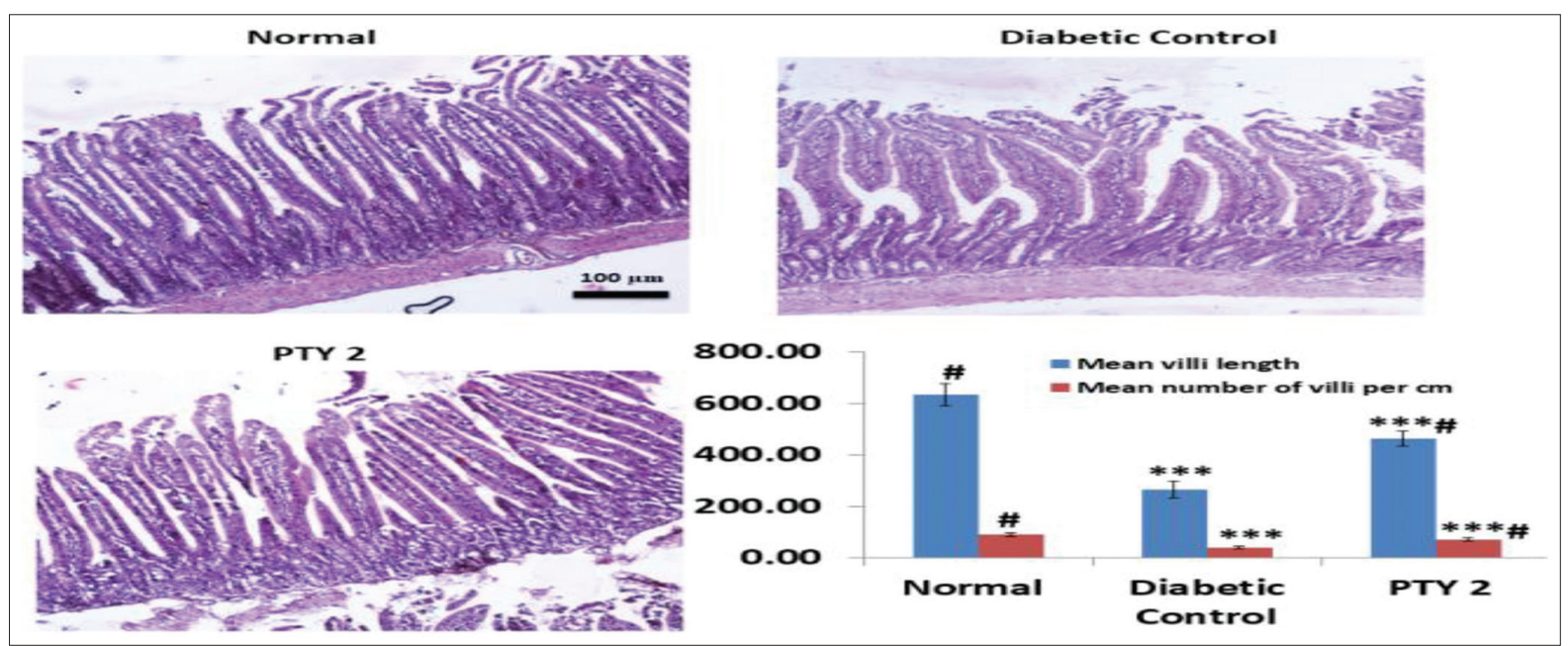

Figure 1: Hematoxylin-eosin staining to measure the morphological changes of intestinal villi. PTY-2 treatment showed a recovery of streptozotocin-induced villi damage. The image was taken at 20x. Scale bar $100 \mu \mathrm{m}$

Table 1: Details of PCR primer sequences, product size, and thermal steps for expressions of DPP-IV, SOD, and GAPDH

\begin{tabular}{|c|c|c|c|c|c|c|c|c|}
\hline \multirow[t]{2}{*}{ Primers } & \multirow[t]{2}{*}{ Sequence } & \multirow{2}{*}{$\begin{array}{l}\text { Product } \\
\text { Size (bp) }\end{array}$} & \multicolumn{6}{|c|}{ RT PCR Thermal steps } \\
\hline & & & & Initial denaturation & Denature & Anneal & Extension & Final Extensior \\
\hline DPP-IV FORW & 5'- ACTACTACTACGATTCCCATG -3' & 546 & No. of Cycle & 1 & 30 & & & 1 \\
\hline DPP-IV REV & & & Temp. $\left({ }^{\circ} \mathrm{C}\right)$ & 95 & 95 & 55 & 72 & 72 \\
\hline & 5'- TGTACAGACCTGTTCGGG-3' & & Time & $2 \min$ & $1 \mathrm{~min}$ & $1 \mathrm{~min}$ & $2 \min$ & $5 \mathrm{~min}$ \\
\hline SOD FORW & 5'-TCTAAGAAACATGGC GGTCC-3' & 387 & No. of Cycle & 1 & 35 & & & 1 \\
\hline SOD REV & 5'-CAGTTAGCAGGCCAGC AGAT-3' & & Temp. $\left({ }^{\circ} \mathrm{C}\right)$ & 94 & 94 & 55 & 72 & 72 \\
\hline GAPDH FORW & 5'-CACGGCAAGTTCAAT GGCACA-3' & 244 & No. of Cycle & 1 & $\begin{array}{l}45 s \\
35\end{array}$ & & $1.3 \mathrm{~min}$ & 1 \\
\hline & & & Temp. $\left({ }^{\circ} \mathrm{C}\right)$ & 94 & 94 & 58 & 72 & 75 \\
\hline GAPDH REV & 5'-GAATTGTGAGGGAGAG TGCTC-3' & & Time & $3 \mathrm{~min}$ & $30 \mathrm{~s}$ & $30 \mathrm{~s}$ & $45 \mathrm{~s}$ & $5 \mathrm{~min}$ \\
\hline
\end{tabular}



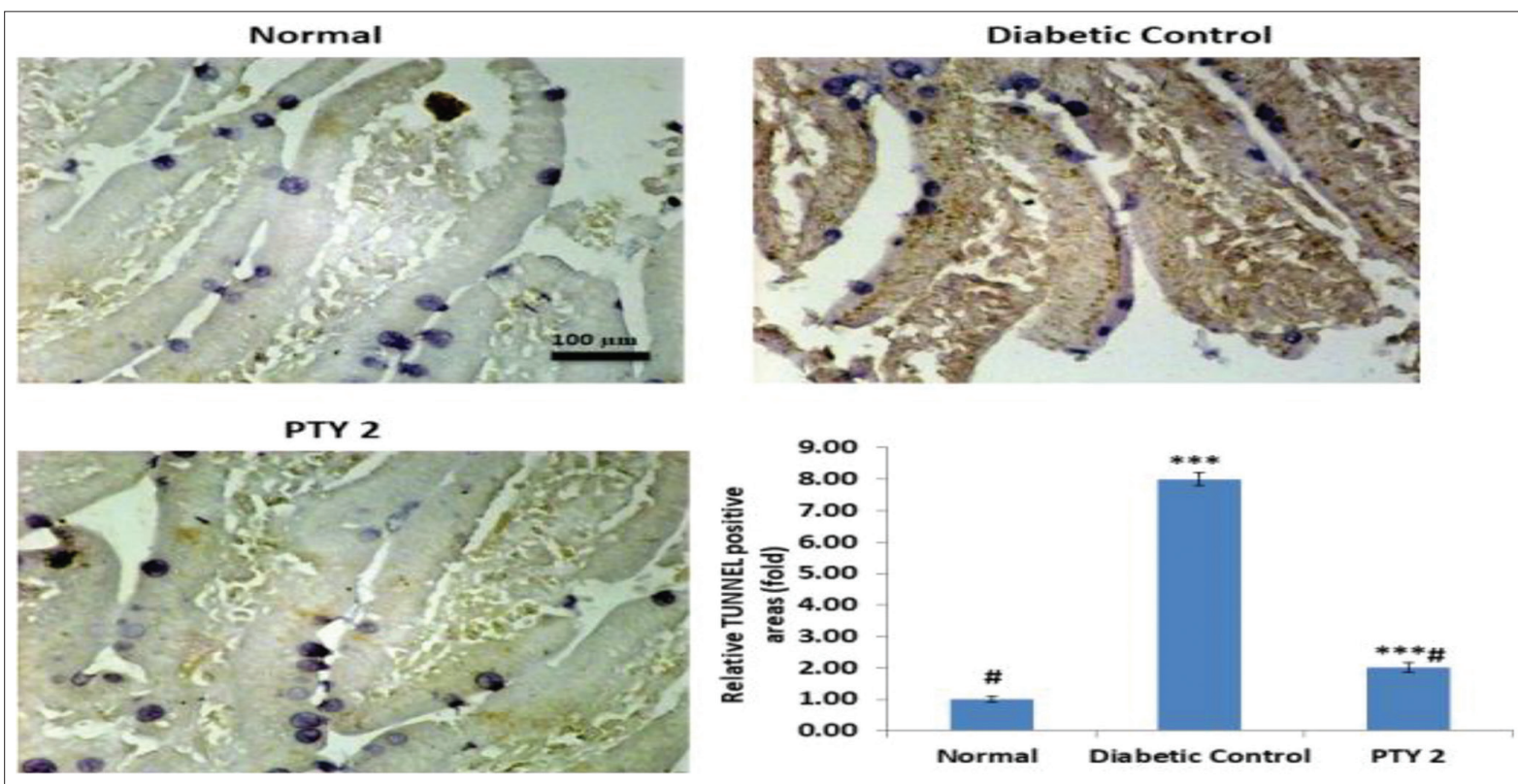

Figure 2: Tunnel assay analysis showed the effect of PTY-2 on intestinal cells apoptosis. PTY-2 recovers the apoptosis induced by streptozotocin. The image was taken at 40x. Scale bar $100 \mu \mathrm{m}$. The brownish color indicates the TUNEL-positive area

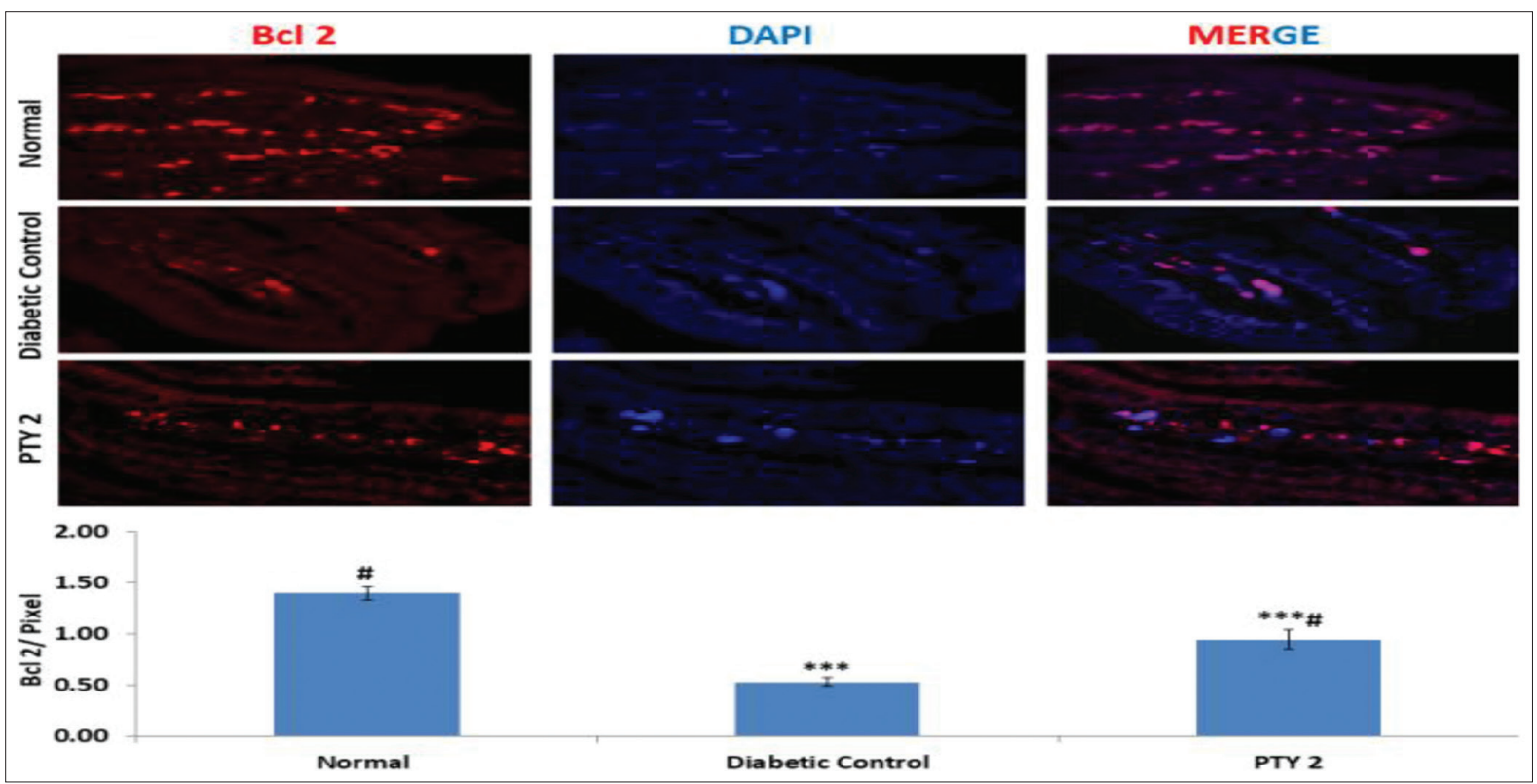

Figure 3: Immunohistochemistry analysis in the intestine of normal, diabetic control, and PTY-2 treated rats to show the effect of PTY-2 on the intestinal apoptosis. The expression was merged with DAPI (blue). In comparison to diabetic control, PTY-2 upregulated the expression of BCI 2. The image was taken at $63 \times$. The scale bar was $20 \mu \mathrm{m}$. The intensity was measured in pixel values. Each value represent the mean $\pm S D$ $(n=6) ;{ }^{* * *} p<0.05$, compared with normal, \# $p<0.05$, compared with diabetic control

Some of these alterations are caused by the oxidative stress raised during diabetic complications, studied in STZ-induced diabetic rats [22]. An increase in the intestinal DPP-IV activity is associated with diabetes development [23]. In our case, the enhanced expression of DPP-IV, reduced expression of SOD, apoptosis, and deformities of intestinal morphology clearly indicates the high uptake of STZ by intestinal mucosa as discussed above. PTY 2 recovers this damages by upregulating the antioxidant enzyme SOD and downregulating DPP-IV mRNA expressions (Figure 4). Thus, reduced stress leads to a significant increase in the number and length of villi as compared to STZ treated group (Figure 1). The apoptosis assay and $\mathrm{Bcl} 2$ protein expression also showed the anti-apoptotic and protective effect on intestinal cells by PTY 2 (Figures 2 and 3 ).

GLP-1 assimilates nutrients while GLP 2 acts as a regulator of energy absorption by means of mucosal permeability, nutrient absorption, nutrient intake, gastric emptying, and gastric acid secretion [24]. Both GLP-1 and GLP 2 have been proved to play 


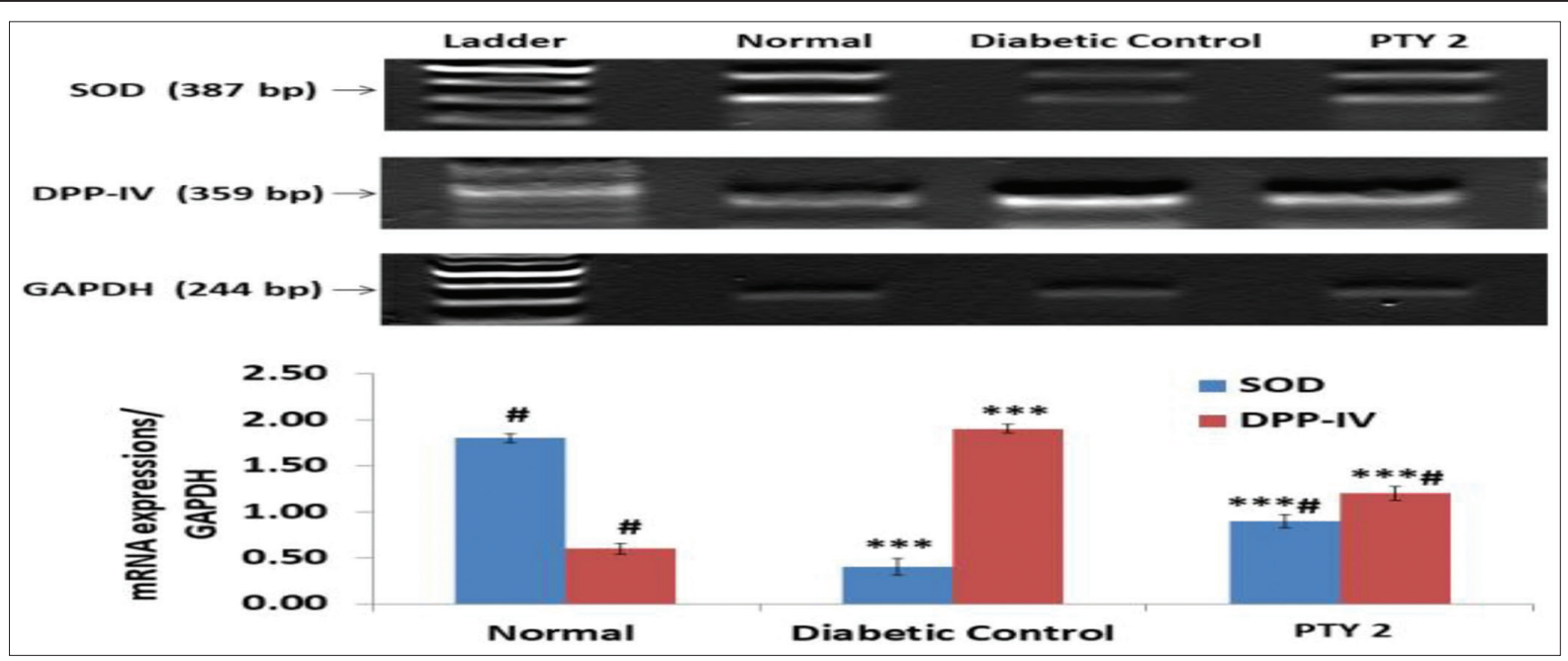

Figure 4: Messenger ribonucleic acid expression of superoxide dismutase and dipeptidyl-peptidase IV on the intestinal tissues of normal, diabetic control, and PTY-2 treated rats to investigate the effect of PTY-2 on stress. Each value represent the mean $\pm S D(n=6) ;{ }^{* * *} p<0.05$, compared with normal, \#p < 0.05, compared with diabetic control

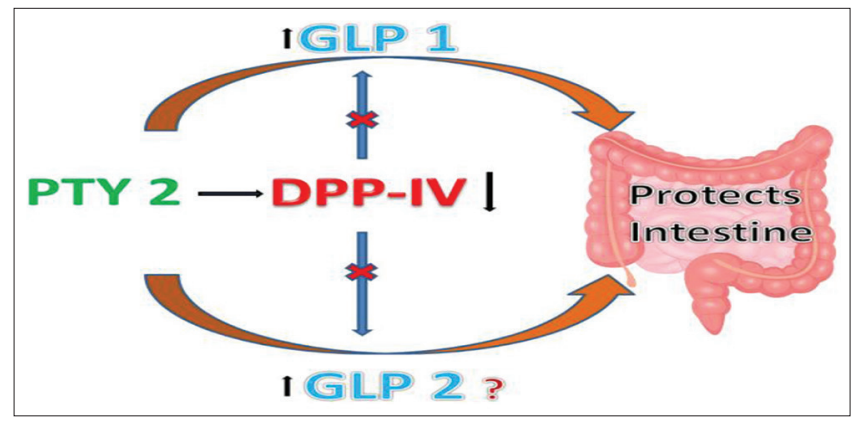

Figure 5: Signaling pathway of Pueraria tuberosa tuber water extract acting against diabetes-induced intestinal damage

the essential regenerative and healing role against intestinal injury in mice [25]. Through the mechanism involving Fgf 7, GLP-1R improves both small and large bowel growth [26]. GLP-2 administration in mice has been shown to regulate both cell proliferation and apoptosis as well as promote the increase in height of the small intestinal villous [27]. In our previous works, we have already proved PTY 2 as an incretin hormones (GLP-1 and GIP) enhancing agent. It significantly inhibits DPP-IV and enhances the levels of GLP-1 and GIP. In addition to DPP-IV inhibition, it also acts as an incretins receptor (GLP-1R and GIP$\mathrm{R})$ agonist [10], [11], [12],16]. As DPP-IV inhibitor, PTY 2 must also enhance the intestinotrophic effect of GLP 2.

In Sprague Dawley diabetic rat model, STZ altered the microbiota compositions and decreased microbial diversity with time [28]. PTY 2 improves the villi count and length, thus enhances the surface area to assimilate more nutrients from diet and could also provide the maximum space for the colonization of positive bacteria useful for intestinal health. A detail of the study is needed to reveal the role of PTY 2 and its individual active constituents in the future at molecular, microbial as well as clinical levels against diabetesinduced intestinal complications.

\section{Conclusion}

PTY 2 recovers the STZ-induced stress, improves the intestinal morphology, increases the villi number and length as well as prevents apoptosis. As a DPP-IV inhibitor, PTY 2 increases the glucagon-like peptides which have positive intestinal health effects, thus, it must act as an effective herbal agent for the treatment of intestinal diseases (Figure 5). Overall, PTY 2 has multiple medicinal roles if taken with proper knowledge of preparation, dose, and duration.

\section{Authors' Contributions}

S. Srivastava conceived, designed, implemented, and analyzed the data for all the experiments and wrote the manuscript. $\mathrm{H}$ and $\mathrm{E}$ was done by $\mathrm{H}$. Pandey. Y.B. Tripathi, and S.K. Singh provided guidance for all levels from conception to manuscript writing.

\section{Acknowledgment}

We are thankful to Prof. Shail Kumar Chaube and his students, Department of Zoology, Institute of Sciences, BHU, for their help in tunnel assay. 


\section{Ethics Approval and Consent to Participate}

Institute Ethical Committee (Dean/2015/ CAEC/1266), Institute of Medical Sciences, Banaras Hindu University has approved the overall protocol.

\section{References}

1. Akinola OB, Zatta L, Dosumu OO, Akinola OS, Adelaja AA, Dini L, et al. Intestinal lesions of streptozotocin-induced diabetes and the effects of Azadirachta indica treatment. Pharmacologyonline. 2009;3:872-81.

2. Karaca T, Uslu S, Yörük M. Effects of green tea and ginseng on villus length and crypt depth and on the distribution of mast and goblet cells in the small intestine of rats with streptozotocin (stz)-induced diabetes. Philipp J Vet Med. 2011;48(2):86-94.

3. Lambeir AM, Durinx C, Scharpé S, De Meester I. Dipeptidylpeptidase IV from bench to bedside: An update on structural properties, functions, and clinical aspects of the enzyme DPP IV. Crit Rev Clin Lab Sci. 2003;40(3):209-94. https://doi. org/10.1080/713609354

\section{PMid: 12892317}

4. Burcelin R. The gut-brain axis: A major glucoregulatory player. Diabetes Metab. 2010;36(3):S54-8. https://doi.org/10.1016/ s1262-3636(10)70468-7

PMid:21211737

5. Yusta B, Holland D, Waschek JA, Drucker DJ. Intestinotrophic glucagon-like peptide-2 (GLP-2) activates intestinal gene expression and growth factor-dependent pathways independent of the vasoactive intestinal peptide gene in mice. Endocrinology. 2012;153(6):2623-32. https://doi.org/10.1210/en.2012-1069 PMid:22535770

6. Brubaker PL, Izzo A, Hill M, Drucker DJ. Intestinal function in mice with small bowel growth induced by glucagon-like peptide-2. Am J Physiol. 1997;272(6):E1050-8.

PMid:9227451

7. Hartmann B, Thulesen J, Kissow H, Thulesen S, Orskov C, Ropke C, et al. Dipeptidyl peptidase IV inhibition enhances the intestinotrophic effect of glucagon-like peptide-2 in rats and mice. Endocrinology. 2000;141(11):4013-20. https://doi. org/10.1210/endo.141.11.7752

PMid:11089531

8. Darmoul D, Rouyer-Fessard C, Blais A, Voisin T, Sapin C, Baricault L, et al. Dipeptidyl peptidase IV expression in rat jejunal crypt-villus axis is controlled at mRNA level. Am J Physiol. 1991;261(5):G763-9. https://doi.org/10.1152/ ajpgi.1991.261.5.g763

PMid: 1683165

9. Inoue T, Higashiyama M, Kaji I, Rudenkyy S, Higuchi K, Guth PH, et al. Dipeptidyl peptidase IV inhibition prevents the formation and promotes the healing of indomethacin-induced intestinal ulcers in rats. Dig Dis Sci. 2014;59(6):1286-95. https:// doi.org/10.1007/s10620-013-3001-6

PMid:24379150

10. Srivastava S, Koley TK, Singh SK, Tripathi YB. The tuber extract of Pueraria tuberosa Linn. competitively inhibits DPP-IV activity in normoglycemic rats. Int J Pharm Pharm Sci. 2015;7(9):227-31.

11. Srivastava S, Shree P, Tripathi YB. Active phytochemicals of
Pueraria tuberosa for DPP-IV inhibition: In silico and experimental approach. J Diabetes Metab Disord. 2017;16(1):46. PMid:29201861

12. Srivastava S, Yadav D, Tripathi Y. DPP-IV inhibitory potential of methanolic extract of Pueraria tuberosa in liver of alloxan induced diabetic model. Biosci Biotechnol Res Asia. 2018;15(1):1-4.

13. Srivastava S, Pandey H, Singh SK, Tripathi YB. Anti-oxidant, anti-apoptotic, anti-hypoxic and anti-inflammatory conditions induced by PTY-2 against STZ-induced stress in islets. Biosci Trends. 2019;13(5):382-93.

PMid:31597821

14. Pandey N, Tripathi YB. Antioxidant activity of tuberosin isolated from Pueraria tuberose Linn. J Inflamm (Lond). 2010;7:47. https://doi.org/10.1186/s40200-017-0328-0

PMid:20836891

15. Pandey N, Yadav D, Pandey V, Tripathi YB. Antiinflammatory effect of Pueraria tuberosa extracts through improvement in activity of red blood cell antioxidant enzymes. Ayu. 2013;34(3):297-301. https://doi. org/10.4103/0974-8520.123131

PMid:24501527

16. Srivastava S, Shree P, Pandey H, Tripathi YB. Incretin hormones receptor signaling plays the key role in antidiabetic potential of PTY-2 against STZ-induced pancreatitis. Biomed Pharmacother. 2018;97:330-8. https://doi.org/10.1016/j.biopha.2017.10.071 PMid:29091882

17. Tripathi YB, Shukla R, Pandey N, Pandey V, Kumar M. An extract of Pueraria tuberosa tubers attenuates diabetic nephropathy by upregulating matrix metalloproteinase-9 expression in the kidney of diabetic rats. J Diabetes. 2017;9(2):123-32. https:// doi.org/10.1111/1753-0407.12393

PMid:26924185

18. Pramanik SS, Sur TK, Debnath PK, Bhattacharyya D. Effect of Pueraria tuberosa tuber extract on chronic foot shock stress in Wistar rats. Nepal Med Coll J. 2010;12(4):234-8.

PMid:21744765

19. Verma SK, Jain V, Singh DP. Effect of Pueraria tuberosa DC. (Indian Kudzu) on blood pressure, fibrinolysis and oxidative stress in patients with stage 1 hypertension. Pak J Biol Sci. 2012;15(15):742-7. https://doi.org/10.3923/pjbs.2012.742.747 PMid:24171260

20. Asthana S, Agarwal T, Singothu S, Samal A, Banerjee I, Pal K, et al. Molecular Docking and Interactions of Pueraria tuberosa with vascular endothelial growth factor receptors. Indian J Pharm Sci. 2015;77(4):439-45. https://doi. org/10.4103/0250-474x.164780

PMid:26664060

21. Tripathi AK, Kohli S. Anti-diabetic activity and phytochemical screening of crude extracts of Pueraria tuberosa DC. (FABACEAE) grown in India on STZ-induced diabetic rats. Asian J Med Pharm Res. 2013;3(3):66-73.

22. Bhor VM, Raghuram N, Sivakami S. Oxidative damage and altered antioxidant enzyme activities in the small intestine of streptozotocin-induced diabetic rats. Int $\mathrm{J}$ Biochem Cell Biol. 2004;36(1):89-97. https://doi.org/10.1016/ s1357-2725(03)00142-0

PMid: 14592535

23. Yang J, Campitelli J, Hu G, Lin Y, Luo J, Xue C. Increase in DPP-IV in the intestine, liver and kidney of the rat treated with high fat diet and streptozotocin. Life Sci. 2007;81(4):272-9. https://doi.org/10.1016/j.Ifs.2007.04.040 PMid: 17583752

24. Drucker DJ. Gut adaptation and the glucagon-like peptides. Gut. 2002;50(3):428-35. https://doi.org/10.1136/gut.50.3.428 


\section{PMid:11839727}

25. Hytting-Andreasen R, Balk-Møller E, Hartmann B, Pedersen J, Windeløv JA, Holst JJ, et al. Endogenous glucagon-like peptide1 and 2 are essential for regeneration after acute intestinal injury in mice. PLoS One. 2018;13(6):e0198046. https://doi. org/10.1371/journal.pone.0198046

\section{PMid:29864142}

26. Koehler JA, Baggio LL, Yusta B, Longuet C, Rowland KJ, Cao X, et al. GLP-1R agonists promote normal and neoplastic intestinal growth through mechanisms requiring Fgf7. Cell Metab. 2015;21(3):379-91.

PMid:25738454
27. Tsai CH, Hill M, Asa SL, Brubaker PL, Drucker DJ. Intestina growth-promoting properties of glucagon-like peptide-2 in mice. Am J Physiol. 1997;273(1):E77-84. https://doi.org/10.1016/j. cmet.2015.02.005

PMid:9252482

28. Patterson E, Stanton C, Cryan JF, Fitzgerald GF, Ross RP, Dinan TG, et al. Streptozotocin-induced Type-1-diabetes disease onset in Sprague-Dawley rats is associated with an altered intestinal microbiota composition and decreased diversity. Microbiology. 2015;161(1):182-93. https://doi. org/10.1099/mic.0.082610-0

PMid:25370749 